\title{
THE FACTORS OF QUALITY OF STATISTICAL INFORMATION WHICH IS FORMED BY THE STATE STATISTICS OF UKRAINE ABOUT ADMINISTRATIVE OFFENSES
}

\author{
${ }^{\odot} 2019$ HINCHUK L. I.
}

UDC 311.3:342.9

JEL: D80

\section{Hinchuk L. I. The Factors of Quality of Statistical Information Which is Formed by the State Statistics of Ukraine about Administrative Offenses}

The article considers the factors of ensuring the quality of statistical information of the State statistical observation regarding administrative offenses in Ukraine. It is proved that the category of quality of information about administrative offenses is multifaceted and is defined as a system of measuring the quality of information on administrative misconducts, each of which displays a separate aspect of functioning of society and the State. It is indicated that changes in the legislation and introduction of new reporting forms do not fully reflect the real situation in the sphere of quality of information about administrative offenses in the State because of absence of the data on a significant number of administrative offenses. This arrangement makes it impossible to verify the quality of information about administrative offenses and thus complicates the possibility of developing a system of measures to prevent the commission of new administrative offenses. Improving the quality of the indicated information needs to develop new statistical forms to generalize information on administrative offenses by industry branches, especially concerning administrative offenses in transport, in the customs sphere, and anti-corruption offenses, information on which is the most accessible to date.

Keywords: administrative offenses, the State statistical observation, quality of statistical data.

DOI: https://doi.org/10.32983/2222-4459-2019-6-95-99

Bibl.: 9 .

Hinchuk L. I. - Head of the Department of Legal Support, State Statistics Service of Ukraine (3 Shota Rustaveli Str., Kyiv, 01601, Ukraine)

E-mail: mega.19841212@ukr.net

ORCID: https://orcid.org/0000-0002-6448-9744

Гінчук Л. І. Чинники якості статистичної інформачії про адміністративні правопорушення, яку формує державна статистика України

у статті розглянуто чинники забезпечення якості статистичної інформації державного статистичного спостереження щодо адміністративних правопорушень в Україні. Доведено, що категорія якості інформації про адміністративні правопорушення $є$ багатоаспектною та визначається як система вимірів якості інформачії про адміністративні проступки, кожен з яких відображає окремий аспект життєдіяльності суспільства та держави. Зазначено, що зміни в законодавстві та запровадження нових звітних форм не повною мірою відображають реальну ситуацію у сфері якості інформації про адміністративні правопорушення в державі тому, що інформація про значну кількість адміністративних правопорушень відсутня. Такий стан речей унеможливлює достовірність аналізу якості інформації про адміністративні правопорушення, а отже, ускладнює можливості розроблення системи заходів запобігання вчиненню нових адміністративних правопорушень. Підвищення якості вказаної інформації потребує розроблення нових статистичних форм для узагальнення інфрормації про адміністративні правопорушення по галузях, передусім про адміністративні правопорушення на транспорті, в митній сфері, антикорупиійні правопорушення, інформація щодо яких на сьогодні $\epsilon$ найбільш доступною. Ключові слова: адміністративні правопорушення, державне статистичне спостереження, якість статистичних даних.

Бібл.: 9.

Гінчук Лілія Іванівна - начальник управління правового забезпечення, Державна служба статистики України (вул. Шота Руставелі, 3, Київ, 01601, Україна)

E-mail: mega.19841212@ukr.net

ORCID: https://orcid.org/0000-0002-6448-9744
Гинчук Л. И. Факторы качества статистической информации об административных правонарушениях, которую формирует государственная статистика Украины

B статье рассмотрены факторы обеспечения качества статистической информации государственного статистического наблюдения относительно административных правонарушений в Украине. Доказано, что категория качества информации об административных правонарушениях является многоаспектной и определяется как система измерений качества инсрормации об административных проступках, в кандом из которых отображает отдельный аспект жизнедеятельности общества и государства. Указано, что изменения в законодательстве и внедрение новых отчетных форм не в полной мере отображают реальную ситуацию в сфере качества информации об административных правонарушениях в государстве потому, что информация о значительном количестве административных правонарушений отсутствуeт. Такой порядок вещей делает невозможным достоверность анализа качества информации об административных правонарушениях, а следовательно, усложняет возможности разработки системы мер по предотвращению совершения новых административных правонарушений. Повышение качества указанной информмации нуждается в разработке новых статистических форм для обобщения инфформации об административных правонарушениях по отраслям, прежде всего об административных правонарушениях на транспорте, в тамоненной сфере, антикоррупционные правонарушения, информация относительно которых на сегодня является наиболее доступной.

Ключевые слова: административные правонарушения, государственное статистическое наблюдение, качество статистических данных. Библ.: 9.

Гинчук Лилия Ивановна - начальник управления правового обеспечения, Государственная служба статистики Украины (ул. Шота Руставели, 3, Киев, 01601, Украина)

E-mail: mega.19841212@ukr.net

ORCID: https://orcid.org/0000-0002-6448-9744 
T he purpose of statistical observation of social and legal phenomena and processes is to obtain data on the basis of which a generalized characteristic of the state and development of a legal phenomenon or process can be formed with the determination of the corresponding objective laws [1]. The ultimate goal of monitoring the phenomena and processes of the kind is to prepare a managerial decision to take appropriate measures. In particular, the purpose of administrative and legal statistics is to determine the level of commission of administrative offenses with the aim of developing and implementing measures to prevent these offenses, identify and eliminate the causes and conditions conducive to their commission as well as educate citizens in the spirit of high consciousness and discipline, strict adherence to the laws of Ukraine.

Statistical information is documented information that gives a quantitative characteristic of mass phenomena and processes occurring in the economic, social, cultural and other spheres of the society's life. The nature of information can be either absolute or relative. Its relative character is expressed in the fact that an object is a source of information only in relation to another, clearly defined object, when the latter, under certain conditions, is able to perceive and use this information for their own personal goals. Its absolute character is expressed in the fact that there are no material objects the information about which would be absent.

It should be noted that statistical information obtained on the basis of statistical surveys carried out by state statistics bodies exists in the form of primary data on the respondents, statistical data, which have undergone one or several stages of processing and accumulated on paper, magnetic and other carriers or electronically as well as analytical materials prepared on the basis of these data. Primary data are information on quantitative and qualitative characteristics of phenomena and processes that is submitted by respondents during statistical observations. While statistical data are information obtained on the basis of statistical observations that has been processed and filed in a formalized form in accordance with the generally accepted principles and methodology. The statistical data resulting from the collapse and grouping of primary data, provided that they are depersonalized, constitute a summary of depersonalized statistical information (data).

The difference between information and data is that data are a set of fixed knowledge stored on certain media, while information is obtained as a result of processing and analyzing data for specific tasks. It should be noted that information may not be transmitted, received or stored in its pure form or in its original form. Nowadays, in the world, there observed a rapid growth of demand for all types of information and at the same time increasing requirements for its content and forms of provision. In the economies of countries there is a significant increase in the role of economic activities associated with the production and distribution of information products $[2 ; 3]$.

The necessity of developing information systems in statistical surveys with their subsequent use for quality management is evidenced by a number of normative acts that have been adopted in Ukraine in recent years. Thus, the Law of Ukraine "On Electronic Documents and Electronic Document Circulation" of 22.05.2003 No. 851-IV, the Law of Ukraine "On Electronic Digital Signature" dated May 22, 2003 No. 852-IV, and other enactments of the State Statistics Service regarding the functioning of the electronic reporting system in state statistics bodies, taking into account the main ways of developing the statistical reporting system as a whole, and statistical information and reporting on administrative violations in particular, emphasize the need for the implementation of management accounting on the basis of information technologies.

$\mathrm{T}$ he process of forming an information base for managing socio-economic phenomena and processes requires clear planning of the first stage of a statistical research, which is statistical observation. The task of statistical observation is to register individual facts about the objects of the population under study, in particular on administrative offenses [9] and their features (qualification of an administrative offense, place and time of its commission, damage caused, etc.). Taking this into account, P. Alekseev singled out two levels in determining quality:

+ phenomenological: quality is a system of the most important, necessary properties of an object. The selection of properties that correlate with the quality of the object is at the same time the movement of knowledge from the external quality characteristics of the object to its essence. Its essential moments are already manifested in its most important and necessary properties. Full transition to the essential level of the object means the identification of its structure, the basic law of the relationship between its elements.

+ essential: quality is integrity similar to internal certainty (the basic law of the object).

It is generally accepted to distinguish such objects of quality as material products, processes, environments, living beings (people), information, life, etc. And depending on the object of the study - such aspects of the concept of quality as philosophical, economic, social, technical, managerial, personal, etc.

It should be noted that the socio-economic aspect of the category "quality" is determined by the nature of the attitude of members of social groups and society as a whole to the results of their work and the degree of satisfaction of their needs. In the economy and management, the term "quality" relates primarily to production and consumption of products and services, and therefore their quality is the object of research and management. 
The technical aspect of quality is characterized by a combination of properties of a product, functionality of its individual properties, their intensity compared with similar properties in competitive products designed to meet the same needs [10].

The definition of quality is included in standards developed by the International Organization for Standardization (ISO). ISO 9001: 2005 "Quality management systems - Fundamentals and vocabulary" defines product quality (which for statistics is a synonym of quality of statistical information) as "the degree to which a set of inherent characteristics of a product fulfill the requirements" [11].

Thus, quality at the same time is an objective and subjective category, since, on the one hand, it is defined as a combination of characteristics of an object provided by a producer independently of consumers, and, on the other hand, is determined by requirements of consumers that can be different. The approach to determining the quality of user-oriented statistical information suggests that it is users who determine quality requirements for statistical products. The definition of quality concerns both statistical information and processes of its production.

0 ummarizing the above, one can conclude that quality of statistical information can be defined as a set of properties and characteristics of the initial statistics and/or services, which enables to meet existing or foreseen needs of consumers [12].

The quality of statistical observation data on which the results of further research depend must meet certain requirements [9]. In accordance with the "Assessment of Quality in Statistics" by European Statistical System (hereinafter referred to as the ESS), the quality of statistical information is assessed through the following dimensions: relevance, accuracy and reliability, timeliness and punctuality, coherence and comparability, accessibility and clarity [13].

The quality of statistical data is largely determined by the level at which they are collected. There are two systems of collecting data on administrative violations in Ukraine: centralized (national) and decentralized (departmental, separate law-enforcement structures). The centralized system of data collection has wider quality assurance capabilities: scientifically based methodology, skilled personnel, appropriate technical support, etc. However, the decentralized system is more operational due to the shorter time between collecting data and using ready-made statistical information. At the same time, for the decentralized system, the problem of developing scientifically based methods of statistical observation and their practical application is relevant [9].

The UN Statistical Commission, Eurostat, has developed documents that regulate the requirements for quality of statistical data and methods for its provision, contain recommendations for the programs and content of the reporting documentation regarding the quality of data for users and experts in statistics, etc. On this basis, relevant documents are also developed by national statistical services [14].

W ithin the framework of Article 15 of the Law of Ukraine "On State Statistics", a long-term program for the development of state statistics is elaborated in order to ensure continuous improvement of quality of statistical information and determine the future objectives and strategic directions for the development of state statistics and authorized state bodies [15]. According to the Strategy for the development of state statistics for the period up to 2017, approved by the Decree of the Cabinet of Ministers of Ukraine dated 20.03.2013 No. 145-p, it is planned to create a system for the preparation and publication of reports on the quality of state statistical observations [16]. However, due to the lack of a special regulatory framework, in particular, a legal act that would determine the organizational and legal framework, the procedure for the formation and filling of the system of preparation and publication of reports on the quality of data of state statistical observations, which should be obtained/produced in accordance with the processes of the Generic Statistical Business Process Model (GSBPM), the latter has not been created. This may also result from neglecting the need to introduce in the bodies of state statistics the system for quality management of production of state statistical observation data in accordance with the requirements of the State Standard of Ukraine (DSTU) ISO 9001:2015 “Quality management system. Requirements" with regard to the relevant processes of the GSBPM, despite the fact that this standard came into force on 01 July $2016[11 ; 16]$.

At the same time, despite the foregoing, state statistics bodies compile quality reports, which is a starting point for the development of a quality system of reports aimed at both users and producers of statistical information and intended to meet their need for quality information and processes of certain state statistical observations. The reports contain information on the components of the quality of state statistical monitoring, and the report itself is an integral part of the system for preparing and publishing reports on the quality of government statistical observations. A quality report is compiled for each state statistical observation only once and updated in the event of changes in key metadata (monitoring methodology, procedures, statistical production processes, classifications, key statistical indicators, etc.) [17].

At the same time, a separate report on the quality of data from the state statistical monitoring of administrative offenses was not drawn up till 2017.

The report on this observation should contain information about the following components of its quality:

1) relevance of the statistical data on administrative violations. This information characterizes the degree of correspondence to the needs of users of the information on indicators of compliance with the requirements of ad- 
ministrative legislation in Ukraine in the publications of the State Statistics Service of Ukraine, in particular, the bulletins "Administrative Offenses in Ukraine" and similar statistical publications of the territorial bodies of state statistics;

2) accuracy and reliability of statistical data on administrative violations. This refers to information on assessment and verification of primary statistics, interim results and initial statistical data on administrative violations in the context of their relevance to the real values. The report should also include information on mistakes, whether related to the sample or not, and their analysis in accordance with the quality components of the ESS in order to improve statistical methods and procedures;

3) timeliness and punctuality concerning the periodicity of distribution of statistical data on administrative violations in Ukraine. This information should include data on the timing of the dissemination of statistical information in accordance with international standards and requirements, possible deviations from the timetable for the dissemination of statistical information and the previous consolidated data, their usefulness for users;

4) accessibility and clarity or description of the access to statistical data on administrative violations in Ukraine and the form of its distribution among users. This also applies to information on the use of microdata for scientific purposes, access to them, methodology of statistical calculations and quality of statistical information on administrative offenses in accordance with the quality criteria defined by the ESS;

5) coherence and comparability - harmonization of statistics and their comparability in time, by region and country, as well as statistics obtained from different sources. Information about the data source should be assessed on the basis of general standards on the coverage, definitions, units of measurement and classifications, international comparability of data on administrative violations in accordance with international norms and standards.

Also, a separate section of the quality report presents an assessment of the needs and expectations of users, determination of the usefulness of the available statistical information to meet their current and future priority needs. The assessment should be carried out with regard to the cost-effectiveness and burden on respondents, confidentiality, transparency, and protection of data on administrative offenses in Ukraine [13].

$\mathrm{T}$ hus, the information on administrative offences, produced by the state statistics bodies should be a product of high quality to meet the European requirements. And for this purpose, first of all, the quality management system should operate based on the national standard DSTU ISO 9001:2015 "Quality management system. Requirements". Furthermore, it is necessary to continue to prepare a report on quality of the state statistical supervision on administrative offenses, which has to be included as a compound to system of preparation and publication of reports on quality of data of the state statistical supervision [17].

In this case, the factors affecting quality of information about administrative violations can be divided into the following groups:

+ National - these are certain national peculiarities of the production of statistical information and requirements imposed on it;

+ Political - those influencing the quality of information policy of a country, which determines the structure of the economy and, accordingly, approaches to quality;

+ Technical - quality of information depends on the technical level of its production;

+ Economic - quality of information is closely related to its consumer value, as already noted (cost of quality - its consumer value);

+ Social - the factors which affect the social environment.

$\boldsymbol{T}_{\mathrm{i}}^{\mathrm{t}}$ should be noted that due to the fact that information about a large number of administrative offenses is lacking, the reliability of the analysis of quality of information on administrative violations is decreasing, which complicates the possibility of preventing the commission of new administrative offenses.

This indicates the need to develop additional statistical forms for generalizing information on administrative offenses by industry. In particular, those the information about which is most accessible - transport, customs, anti-corruption sphere.

Currently, despite the growing demand for statistical information on administrative violations, the main goal of producers of administrative statistics is not to increase the amount of statistical information on administrative violations in general but to increase the volume of information of high quality.

\section{LITERATURE}

1. Новейший философский словарь / сост. А. А. Грицанов. Мн. : Изд. В. М. Скакун, 1998. 896 с.

2. Закон України «Про інформацію» від 2 жовтня 1992 р. № 2657-XII. URL: https://zakon.rada.gov.ua/laws/show/2657-12

3. Закон України «Про науково-технічну інформацію» від 25 червня 1993 р. № 3322-XII. URL: https://zakon.rada.gov. ua/laws/show/3322-12

4. Закон України «Про електронні документи та електронний документообіг» від 22.05 .2003 р. № 851-IV. URL: https://zakon.rada.gov.ua/laws/show/851-15

5. Закон України «Про електронний цифровий підпис» від 22.05.2003 р. № 852-IV. URL: https://zakon.rada.gov. ua/laws/show/852-15

6. Наказ Державного комітету статистики України «Про забезпечення функціонування системи електронної звітності в органах державної статистики» від 08.07.2010 р. № 261. URL: https://zakon.rada.gov.ua/rada/show/v0261202-10 
7. Наказ Державного комітету статистики України «Про затвердження Порядку подання електронної звітності до органів державної статистики» від 12.01.2011 р. № 3. URL: https://zakon.rada.gov.ua/laws/show/z0408-11

8. План заходів щодо забезпечення функціонування системи електронної звітності в органах державної статистики від 08.07.2010 р. № 261. URL: http://www.ukrstat.gov.ua/ elektr_zvit/norm.htm

9. Калачова І. В., Трофімова Г. Г. Правова статистика : навч. посіб. Київ : КНЕУ, 2006. 300 с.

10. Алексеев П. В., Панин А. В. Философия : учебник. М. : Проспект, ТК Велби, 2005. 608 с.

11. ДСТУ ISO 9001:2015. Системи управління якістю. Вимоги (ISO 9001:2015, IDT). URL: http://online.budstandart. com/ua/catalog/doc-page?id_doc $=64013$

12. Єріна А. М. Статистичне моделювання та прогнозування : навч. посіб. Київ : КНЕУ, 2001. 170 с.

13. Assessment of the Quality in Statistics / Draft Quality Measurement and Reporting Framework. Luxembourg : Eurostat. 2002. 29 p.

14. Осауленко О. Г. Національна статистична система: стратегічне планування, методологія та організація : монографія. Киїа : ДП «Інформ.-аналіт. агентство», 2008. 415 с.

15. Закон України «Про державну статистику» від 17 вересня 1992 р. № 2614-XII. URL: https://zakon.rada.gov.ua/ laws/show/2614-12

16. Розпорядження Кабінету Міністрів України «Про затвердження Стратегії розвитку державної статистики на період до 2017 року» від 20.03.2013 р. № 145-p. URL: https:// zakon.rada.gov.ua/laws/show/145-2013-\%D1\%80

17. Гінчук Л. І. Теоретичні засади забезпечення якості інформації державного статистичного спостереження про адміністративні правопорушення. Статистика України. 2016. № 1. C. 6-11.

Supervisor - Herasimenko S., Doctor of Economics, Professor, Head of the Department of Statistics of the National Academy of Statistics, Accounting and Audit (Kyiv)

\section{REFERENCES}

Alekseyev, P. V., and Panin, A. V. Filosofiya [Philosophy]. Moscow: Prospekt; TK Velbi, 2005.

Assessment of the Quality in Statistics. Draft Quality Measurement and Reporting Framework. Luxembourg: Eurostat, 2002.

"DSTU ISO 9001:2015. Systemy upravlinnia yakistiu. Vymohy (ISO 9001:2015, IDT)“ [DSTU ISO 9001:2015. Quality management systems. Requirements (ISO 9001:2015, IDT)]. http:// online.budstandart.com/ua/catalog/doc-page?id_doc $=64013$

Gritsanov, A. A. Noveyshiy filosofskiy slovar [The newest philosophical dictionary]. Minsk: Izd. V. M. Skakun, 1998.

Hinchuk, L. I."Teoretychni zasady zabezpechennia yakosti informatsii derzhavnoho statystychnoho sposterezhennia pro administratyvni pravoporushennia" [Theoretical principles of ensuring the quality of information of the state statistical monitoring of administrative violations]. Statystyka Ukrainy, no. 1 (2016): 6-11.

Kalachova, I. V., and Trofimova, H. H. Pravova statystyka [Legal statistics]. Kyiv: KNEU, 2006.

[Legal Act of Ukraine] (1992). https://zakon.rada.gov.ua/ laws/show/2657-12
[Legal Act of Ukraine] (1992). https://zakon.rada.gov.ua/ laws/show/2614-12

[Legal Act of Ukraine] (1993). https://zakon.rada.gov.ua/ laws/show/3322-12

[Legal Act of Ukraine] (2003). https://zakon.rada.gov.ua/ laws/show/851-15

[Legal Act of Ukraine] (2003). https://zakon.rada.gov.ua/ laws/show/852-15

[Legal Act of Ukraine] (2010). https://zakon.rada.gov.ua/ rada/show/v0261202-10

[Legal Act of Ukraine] (2011). https://zakon.rada.gov.ua/ laws/show/z0408-11

[Legal Act of Ukraine] (2013). https://zakon.rada.gov.ua/ laws/show/145-2013-\%D1\%80

Osaulenko, O. H. Natsionalna statystychna systema: stratehichne planuvannia, metodolohiia ta orhanizatsiia [National Statistical System: Strategic Planning, Methodology and Organization]. Kyiv: DP «Inform.-analit. ahentstvo», 2008.

"Plan zakhodiv shchodo zabezpechennia funktsionuvannia systemy elektronnoi zvitnosti v orhanakh derzhavnoi statystyky vid 08.07 .2010 r. no. $261^{\prime \prime}$ [Plan of measures for ensuring the functioning of the electronic reporting system in state statistics bodies dated 08.07.2010, no. 261]. http://www.ukrstat. gov.ua/elektr_zvit/norm.htm

Yerina, A. M. Statystychne modeliuvannia ta prohnozuvannia [Statistical modeling and forecasting]. Kyiv: KNEU, 2001. 